Revista Bioética

\title{
RESEARCH
}

\section{Common mental disorders in medical students}

Hironaldo de Jesus Neponuceno ${ }^{1}$, Bárbara Dourado Macedo Souza ${ }^{1}$, Nedy Maria Branco Cerqueira Neves ${ }^{2}$

1. Departamento de Ciências da Saúde, Universidade Salvador (Unifacs), Salvador/BA, Brasil. 2. Departamento de Ética Médica e Bioética, Universidade Salvador (Unifacs), Salvador/BA, Brasil.

\begin{abstract}
There is growing concern in universities about the severity of common mental disorders, which are increasingly recurrent among medical students. Such issues require the multidisciplinary involvement of both academic levels and society in general, especially due to the their associations with possible predictive factors of stress perpetuated in these students. These associations reflect the importance of discussing disorders, correlating them with the impacts evidenced by the psychic interference of those involved. One proposal reflects a debate about what was actually implemented in the university sphere to change the reality of Common Mental Disorders in medical students, focusing on depression and anxiety. From this debate, suggestions of steps to be implemented are made to minimize problems related to the potentially triggering or somatizing origins of Common Mental Disorders in students' lives.
\end{abstract}

Keywords: Patient acuity-Disease. Mental disorders. Students, medical. Universities. Depression. Anxiety.

\section{Resumo}

\section{Transtornos mentais comuns em estudantes de medicina}

Nas universidades cresce a preocupação com a gravidade dos transtornos mentais e cada vez mais recorrentes entre estudantes de medicina. $O$ tratamento requer envolvimento tanto da academia quanto da sociedade em geral, sobretudo porque esses distúrbios podem ser possíveis fatores preditivos de estresse. Daí a importância de discutir o assunto, correlacionando-o aos impactos psíquicos nos graduandos de medicina. A proposta aqui é debater sobre o que realmente foi estabelecido no âmbito universitário para mudar essa realidade, especificamente quanto à depressão e ansiedade. A partir dessa discussão, sugerem-se passos para minimizar fatores desencadeadores desses fenômenos na vida dos discentes.

Palavras-chave: Gravidade do paciente-Doença. Transtornos mentais. Estudantes de medicina. Universidades. Depressão. Ansiedade.

\section{Resumen}

\section{Trastornos mentales comunes en estudiantes de medicina}

En las universidades crece la preocupación por la gravedad de los trastornos mentales, cada vez más recurrentes entre estudiantes de medicina. El tratamiento requiere el involucramiento de la academia y de la sociedad en general, sobre todo porque estos trastornos pueden ser posibles factores predictivos de estrés. De allí la importancia de discutir el tema, correlacionándolo con los impactos psíquicos en los estudiantes de medicina. La propuesta, aquí, es debatir sobre lo que realmente se estableció en el ámbito universitario para cambiar esta realidad, específicamente en lo que se refiere a depresión y ansiedad. A partir de esta discusión, se sugieren pasos para minimizar los factores desencadenantes de estos fenómenos en la vida de los estudiantes.

Palabras clave: Gravedad del paciente-Enfermedad. Trastornos mentales. Estudiantes de medicina. Universidades. Depresión. Ansiedad.

Declaram não haver conflito de interesse. 
The current teaching model distances itself from psychological aspects and approaches technica and scientific training, leaving aside all the essentia elements for the balance between body and mind. In addition, we noted an excessive valorising practices related to good academic performance A dilemma is faced: study hard and have no social life or reconciling study, social life and good quality of life, but becoming a mediocre professional ${ }^{3}$. In view of this reflection, a humane analysis of the exhaustin reality of so many students is necessary, among whic we highlight those of the medicine course

Aspirant physicians face one of the most competitive public entrance exams in Brazil, which had previously affected their emotional state Because it is an extremely individualistic and competitive profession, many of these students gradually develop isolationist tendencies, whose origin is the idea of protection against the voracious competitions intrinsic to the medica the voracious

These students are future graduates of a profession which is idealised and much desired by the population due to the alleged economic success and the status credited to the profession ${ }^{4}$. At the same time, this status contrasts with conflicts related to students' expectation regarding the course, with possible damages to physica and psychological healh. Many students feel constanty judged and demand much of themselves, in dimension peculiar to each, but reflecting the disruption of the illusion of omnipotence attributed to the profession which generates intense stress since the beginning of the academic training.

The competition in the selective process, knowledge overload, excessive workload, difficulty in managing the time between the many academic activities and the little time dedicated to leisure, individualism and the responsibility and social expectations of the physician's role can be mentioned as stress factors physician's role can be mentioned as stress factors in undergraduate medicine courses. Added to this is the frequent contact with death and other numerous pathological processes, the fear of contracting diseases in this context, especially in the physical examination of of impotence in the face of certain diseases ${ }^{5}$.

Such factors, added to individual students' previous experiences, require important reflection about the real origins of vulnerability to occupation exhaustion. This is what highlights a review article on the predisposition of students and physicians to emotional and psychiatric disorders ${ }^{6}$. With the growing discussion about psychiatric disorders in medical students, several universities began to offer support services to these individuals
This support requires greater attention from the academic environment in order to effect the service and stimulate the adherence of the students. However, it is observed that the problem is underestimated in the literature and higher education institutions, since the severity of mental disorders can affect life and obscure the future of these people, and the subjective impacts to their life cannot be dimensioned or compared. It remains to understand them in the context of human relations, seeking to eliminate them in favor of the best quality of life of undergraduate medical students and future patients.

To do so, it is necessary to understand predictive or somatising factors of stress, which are "naturally" perpetuated among these students ${ }^{4}$. Only this way will it be possible to improve medical training introjecting into the students themselves the need for ethics and care, so as to humanise this very competitive profession and, at the same time, so neslected with regard to the mental heath of its 作 ndergraduate students.

According to the Conselho Federal de Medicina - Federal Council of Medicine (CFM) ${ }^{7}$, there is a paradox in the medical context. These professionals would be better able to prevent themselves from health problems because they have more information and therefore would be less frequently ill, following treatment appropriately. However, there is a greater vulnerability among them, which is reflected in low demand for help, many cases of treatment abandonment and a high number of complications. It is difficult to solve such a contradiction in a country like Brazil, which blames the physician rather than encouraging the search for the origins and solutions of this conflict that is not only academic, but above all human and social ${ }^{8}$.

From these reflections arose the concern that uided this article: what has been implemented to change the reality of common mental disorders (CMD) in medical students? Therefore, the objective here is to discuss effective actions with a focus on $\mathrm{CMD}$, considering especially depression and anxiety, conditions capable of perpetuating stress and associated with other disorders.

\section{Materials and method}

This study consists of a systematic review of the literature, whose analysis was developed from data collected from the Scientific Electronic Library Online (SciELO), ResearchGate, Revista USP (USP Journals), in addition to information provided by the Universidade Federal de São Paulo Federal University of Sao Paulo (Unifesp) and the Conselho - CRM/PR (Regiona Council of Medicine of Paranál.

The descriptors "mental disorders"; "menta health"; "medical students"; "medical education"; "psychological stress"; "risk factors"; "prevalence", "depression"; "anxiety"; "suicide"; and "medica work" were considered in the selection of the material. 1,323 papers were found with these terms; However, the research was based on only publications pertinent to the subject investigated.

The following inclusion criteria were previously established: original or review works, available in full and published between 1990 and 2018. Regarding the exclusion criteria, we disregarded texts in duplicate, texts published before 1990 and texts that, although presenting the selected descriptors, did not directly address the proposed theme, analysed by reading the abstracts. The 16 article selected were read in full.

In addition, recent news stories, official websites and reports have been consulted to update the information. Data collection, systematisation, analysis and production of the work occurred between March 2017 and March 2018. The selected articles were considered valid according to the degree of relevance of the subject studied, taking into account those who presented in the title or in the
descriptors used in the search.

Discussion

The increasing academic-social approach of CMD among medical students reflects the negligence of the mental health of those involved, due to the requirements and demands of the course itself and of the profession, which influences the high prevalence of suicide, depression, use of drugs, marital disorders and professional dysfunctions in physicians and medical students, as already reported in the literature

The mental health of health professionals has been a cause of concern for a few decades, considering the stressful character of their work Physicians are highlighted in this group as upon them falls most of the healing expectation of patients through biomedical technology. In this context of anguish, pain and desire for remission, the studen lives involved in extreme study workload, not only in the university, but also outside the academic period.
The amount of theoretical and practical content learned in medical schools can give certain safety in the tenuous line that separates life and death, but it feeds the continuous tension in relation to the external environment, already stressful. Such pressure triggers internal elements of stress that aggravates the psychosomatic situation of the students. Added to this is the demand for early maturity and the burden of responsibility on the individual who decides to give his or her life to the study of the human organism. Therefore, the debate should encompass the necessary psychological preparation for the students in medical courses so that they can graduate with success and and in good health ${ }^{11}$.

The context described engenders predictive factors of psychiatric disorders, including CMD, especially anxiety and depression. Analysing the origin of these disorders can help detect patterns, from which it will be possible to indicate actions to change this reality.

What does the increasing severity of CMD in medicine courses consists of?

The exaggerated use of licit and illicit drugs by most medical students evidences the seriousness of the subject. Studies conducted by a private university in Curitiba showed that $78 \%$ of their students use alcohol, while at the São José do Rio Preto Medical School this percentage was $86 \%$, and $82 \%$ in other colleges in São Paulo. These numbers are not far from the reality in the state of Bahia; For example, $56 \%$ of the medical students in the Faculty of Medicine of the Federal University of Bahia declared alcohol consumption ${ }^{12}$

It is more difficult to ascertain with veracity the use of illicit drugs than the use of alcohol, because this substance, although it causes dependence, is socially admitted in Brazil. Strictly speaking, the term "illicit" has an essentially moral character and, without legal definition, is commonly used to refer in a somewhat inaccurate manner to any natural or artificial chemical or chemical compound that has a psychoactive effect and is prohibited by law $w^{13}$. Thus, "unlawfulness" is and is proh to by law moral conjuncture that exists in a paticular country

Some drugs legally developed for treatment are used for other purposes by people who would not need them. It is the case of anxiolytics and amphetamines, substances most used by students in order to improve attention and/or stay awake for longer, in order to fulfil all the study obligations throughout their medical course ${ }^{12}$. It is an alarming 
reality that can lead to organic weakness, stress an even chemical dependence.

The wear caused by the course is one of the main factors for the increase in the disseminatio of CMD among these students. Study with medical students from Sorocaba revealed that approximatel one quarter of them each year was not fully satisfie with their mental health. However, they refused to seek professional health.

Some of the justifications for this situation are the lack of time, the stigma associated with the us of mental health services, financial costs and fear of curricular consequences. It is a context founded on discrimination regarding mental health and, above all, in the denial of the physician as a vulnerable human being susceptible to physical and psychiatric disorders like anyone else ${ }^{12}$.

The current scenario has demonstrated the harmful effect of $C M D$ on the life of the medica student, without a positive outcome. A study conducted at the State University of Rio Grand do Norte concluded that most students fee overwhelmed by curricular and complementary activities, with little time for leisure. Despite of this, many engage in extra-curricular activities and see to improve their professional curriculum and acquire new technical skills. This attitude further reduces the quality of life of the student, generating dire emotional repercussions ${ }^{15}$.

The symptoms of anxiety and depression among medical students is higher than the average found in the general population indicating that the medical school may be a predisposing fat medical school may be a predisposing factor for these diseases and their consequences ${ }^{8}$. Therefore the care with the student has been debated in
several environments, but the final product of this discussion is still uncertain.

It is important to emphasise that the suffering caused to the student has been one of the main factors for suicide in the medical environment with prevalence directly linked to CMD. Hence the urgency of putting into practice actions that reduce the incidence of CMD in the medicine course. In addition, faced with such neglect for the mental health of these students, full attention is needed on the part of those responsible and involved ${ }^{9}$.

Actions to change the reality of CMD in the course of medicine

There are methods, such as self-applied menta health measurement scales ${ }^{12}$, easy to use and indispensable for early identification of people more susceptible to depressive symptoms. These diagnostic surveys can be applied to students who are in the first and last year of the course and to perfectionist students who do not accept failures in their academic performance. Third and fourth year students were considered the most difficult to diagnose through these tools.

It is necessary to add the detailed analysis of the workload and the way the disciplines are structured and ministered to the tool in order to have more accurate information. According to the students who participated in the study of Lima, Domingues and Cerqueira ${ }^{12}$, the practical and theoretical parts should be more elaborated by the manement and the professors.

An effective alternative can be the offer of psychosocial disciplines, with the aim of expanding the discussion about the interpersonal relationships of medical professionals from the time they start their medical course until the time when they are working in hospitals and clinics as physicians. The development of this skill should highlight the importance of establishing good coexistence, relationship of trust based on respect for colleagues and patients. This type of approach can help the stressed student to regain health and create important personal and professional bonds, expanding his or her circle of social coexistence and horizons from learning from life and academia ${ }^{12}$.

The use of preventive and interventional psychotherapy can also be systematised, in addition to other actions such as the creation of specialised centres for psychological examinations, in order to provide clinical assistance to students. These actions could encourage students to develop strategies for adapting and coping with stressful situations that will be part of their academic and professional life ${ }^{12}$.

This systematisation generates subsidies for the study of historical patterns of the behaviour of students and professionals affected by CMD, allowing to map the evolution and consequences of the phenomenon in the short and long term. This measure will support the students, strengthening the improvement of their the students, strengthening the improvement of their develop throughout their lives.

The work of the University of Brasilia deserves to be highlighted in this regard. The university offers psychopedagogical guidance suggesting treatments through psychotherapeutic groups, with the participation of people with symptoms of depression ${ }^{15,16}$. This strategy, when simulating social exposure, becomes extremely beneficial to participants
Another example that may serve as an inspiration or model for the institutions is the Faculty of Medicine of the Federal University of Goiás. Th institution relies on the Núcleo de Apoio ao Estudan de Medicina - Medical Student Support Centre (Naem) and with the Programa Saudavelment (Healthily Programme), whose function is to atten students presenting risk or psychological distress ${ }^{10}$. However, the functioning of the programme is stil an incipient demand, demonstrating that such aid should really be implemented in institutions ${ }^{18}$.

The two examples show that the best way to fight these disorders is still prevention. The universities and the society in general should prioritise proposals to systematically meet the demands originated by CMD, knowically meet the requirements of the medicine course, the acand the expectations regarding the technical performe the students and the social projections related to their performance It is necessary to invest in the to the pefformation process and to meet the needs of the population.

Creating and perfecting psychological programmes in medical facultes, stimulating student participation since the first year of the course, is viable way to control and minimize these disorders that affect more and more students ${ }^{16}$. These initiatives should receive institutional and academic support to face the stigma of mental disorders in genera. In this sense, developing follow-up programmes that extend throughout the undergraduate cours certainly contributes to deconstruct erroneous socia representations related to CMD.

Medical education has its share of responsibility in the genesis of these disorders, because it reproduces the logics of capitalism, characterized by individualism, competitiveness, market demands and social expectations about the role of the physician. social expectations about the role of the physician. These elements can function as stressors even during

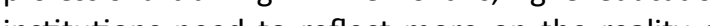
institutions need to refect more on the reality of medcal traning in order to assist these students in the psychiatric, social and spiritual dimensions.

Final considerations

The objective of this work has been achieved, since it expanded the discussion of the academic, social and human perspectives of medical students. The clarifications necessary to understand this alarming reality are based on the breadth of the academic scope, permeating the personal and social Ife of the undergraduate in medicine courses who is faced with several difficulties throughout the course nd the profession.

This theme becomes relevant due to the impact of CMD on the physical and psychiatric health of so many academics, which, in addition to the internal difficulties caused by extreme exhaustion and demands of the course and profession, still deal with such prevalent stigma about mental health. This prejudice is even more socially disseminated when it comes to undergraduate medical students or physicians already active, who are seen only as "caregivers" by the society, as if they were not human beings beyond their specialisations.

From the perspective of bioethics, caregivers of the general population also deserve humanized attention, as well as their patients, because all people dignity. The vund imperfect, deserving respect and dignity. The vulnerability of physicians, which cannot be confused with their professional competence, should be considered so that they can fully perform their activity and devote themselves to this difficult but rewarding work.

From this assessment it is concluded that several stressful factors are associated with the medical course, which is evidenced in the increasing prevalence of CMD and its physical and psychiatric interferences in the lives of these students. Exposing the severity of this situation should alert not only medical schools, reverberating in the students and loved ones, but the whole society, because if care to the health professional remains neglected, the population will become even more forsaken.

Certainly there is still much to discuss about the topic, and it is impossible to exhaust it in this article. However, actions can be suggested to prevent $\mathrm{CMD}$, with the intention of avoiding the causes or asing the burden on the personal experiences of each undergraduate, as exemplified in this work.

Finally, it is proposed that state government bodies oversee higher education institutions, supervising the quality of the support offered to medical students. This monitoring could maintain direct contact with students, from surveys of satisfaction and/or request for suggestions to improve medical education. These would be appropriate tools to reduce the impacts resulting from academic training on the quality of life and well being of medical students and medical professionals. Other measures can be suggested from the study and deeper reflection on the subject. 
We thank Emily Pinto Santos Rios and Xalana Nascimento de Carvalho, who collaborated in the elaboration and writing of the work.

\section{Referências}

1. Rego S. A formação ética dos médicos: saindo da adolescência com a vida (dos outros) nas mãos. Rio de Janeiro: Editora Fiocruz; 2003.

2. Rego STA, Palácios M, Schramm FR. O ensino da bioética nos cursos de graduação em saúde. In: Marins JJN, Rego S, Lampert JB, Araújo JGC, organizadores. Educação médica em transformação: instrumentos para a construção de novas realidades. São Paulo: Hucitec; 2004. p. 165-86.

3. Wuillaume SM. Educação médica em transformação: instrumentos para a construção de novas realidades [resenhas]. Cad Saúde Pública [Internet]. 2005 [acesso 30 jun 2018];21(6):1962-7. DOI: 10.1590/S0102-311X2005000600051

4. Quintana AM, Rodrigues AT, Arpini DM, Bassi LA, Cecim PS, Santos MS. A angústia na formação do estudante de medicina. Rev Bras Educ Méd [Internet]. 2008 [acesso 23 jun 2018];32(1):7-14. DOI: $10.1590 /$ S0100-55022008000100002

5. Fiorotti KP, Rossoni RR, Borges LH, Miranda AE. Transtornos mentais comuns entre os estudantes do curso de medicina: prevalência e fatores associados. J Bras Psiquiatr [Internet]. 2010 [acesso 23 jun 2018];59(1):17-23. DOI: 10.1590/S0047-20852010000100003

6. Johnson WDK. Predisposition to emotional distress and psychiatric illness amongst doctors: the role of unconscious and experimental factors. Br J Med Psychol [Internet]. 1991 [acesso 30 jun 2018];64(4):317-29. DOI: 10.1111/j.2044-8341.1991.tb01670.x

7. Souza JA. Saúde mental do médico. CFM [Internet]. 29 nov 1999 [acesso 23 jun 2017]. Disponível: https://bit.ly/2X9IWys

8. Vasconcelos TC, Dias BRT, Andrade LR, Melo GF, Barbosa L, Souza E. Prevalência de sintomas de ansiedade e depressão em estudantes de medicina. Rev Bras Educ Méd [Internet]. 2015 [acesso 23 jun 2018];39(1):135-42. DOI: 10.1590/1981-52712015v39n1e00042014

9. Martins LAN. Saúde mental do médico e do estudante de medicina. Psychiatry On Line Brasil [Internet]. 1996 [acesso 26 jun 2018];1:1. Disponível: https://bit.ly/2RikZhD

10. Tenório LP, Argolo VA, Sá HP, Melo EV, Costa EFO. Saúde mental de estudantes de escolas médicas com diferentes modelos de ensino. Rev Bras Educ Méd [Internet]. 2016 [acesso 29 jun 2018];40(4):574-82. DOI: 10.1590/1981-52712015v40n4e00192015

11. Harada BA, Faxina CF, Capeletto CM, Simões JC. Perfil psicológico do estudante de medicina. Rev Méd Resid [Internet]. 2013 [acesso 23 jun 2018];15(2):1-13. Disponível: https://bit.ly/2MNBfIU

12. Lima MCP, Domingues MS, Cerqueira ATAR. Prevalência e fatores de risco para transtornos mentais comuns entre estudantes de medicina. Rev Saúde Pública [Internet]. 2006 [acesso 26 jun 2018];40(6):1035-41. DOI: 10.1590/\$0034-89102006000700011

13. Wikipédia: a enciclopédia livre [Internet]. 2019 [acesso 2 abr 2019]. Droga ilícita. Disponível: https://bit.ly/2WHe034

14. Ramos-Dias JC, Libardi MC, Zillo CM, Igarashi MH, Senger MH. Qualidade de vida em cem alunos do curso de medicina de Sorocaba-PUC/SP. Rev Bras Educ Méd [Internet]. 2010 [acesso 4 jun 2018];34(1):116-23. DOI: 10.1590/S0100-55022010000100014

15. Cardoso Filho FAB, Magalhães JF, Silva KML, Pereira ISSD. Perfil do estudante de medicina da Universidade do Estado do Rio Grande do Norte. Rev Bras Educ Méd [Internet]. 2015 [acesso 25 jun 2018];39(1):32-40. Disponível: https://bit.ly/2KhBFVZ

16. Bampi LNS, Baraldi S, Guilhem D, Araújo MP, Campos ACO. Qualidade de vida de estudantes de medicina da Universidade de Brasília. Rev Bras Educ Méd [Internet]. 2013 [acesso 30 jun 2018];37(2):217-25. Disponível: https://bit.ly/2ZqqayS

17. Palmeira WD, Azevedo LL, Loureiro YS, Lucena JPL, Cayana EG. Ansiedade e depressão: desafios a serem superados por acadêmicos de medicina. In: Anais do Congresso Brasileiro de Ciências da Saúde [Internet]; 15-17 jun 2016; Campina Grande. Campina Grande: Conbracis; 2016 [acesso 26 jun 2018]. Disponível: https://bit.ly/2MITxuP

18. Amaral GF, Gomide LMP, Batista MP, Píccolo PP, Teles TBG, Oliveira PM et al. Sintomas depressivos em acadêmicos de medicina da Universidade Federal de Goiás: um estudo de prevalência. Rev Psiquiatria RS [Internet]. 2008 [acesso 26 jun 2018];30(2):124-30. DOI: 10.1590/S0101-81082008000300008

\section{Participation of the authors}

All authors collaborated with the writing of the article. Hironaldo de Jesus Neponuceno e Bárbara Dourado Nascimento de Carvalho reviewed the manuscript, under the guidance of Nedy Maria Branco Cerqueira Neves.

\section{Correspondência}

Nedy Maria Branco Cerqueira Neves - Av. Antônio Carlos Magalhães, 1.034, sala 137, ala A, Itaigara CEP 41825-906. Salvador/BA, Brasil.

Hironaldo de Jesus Neponuceno - Graduando - hiron.neponuceno@hotmail.com (D) 0000-0003-1741-187X

Bárbara Dourado Macedo Souza - Graduanda - barbaradouradoms@hotmail.com

(iD) 0000-0002-3277-8170

Nedy Maria Branco Cerqueira Neves - Doutora - nedyneves@terra.com.br

(iD) $0000-0002-6383-3320$ 


\section{Errata}

In the article "Common mental disorders in medical students", doi 10.1590/1983-80422019273330, in Revista Bioética, published in volume 27, No 3, 2019, pages 465 and 470:

Where it reads:

Bárbara Dourado Nascimento de Carvalho

Reads up:

Bárbara Dourado Macedo Souza 